\title{
Interferon- $\gamma$ Corrects the Respiratory Burst Defect In Vitro in Monocyte-Derived Macrophages from Glycogen Storage Disease Type 1b Patients
}

\author{
LISA J. MCCAWLEY, HELEN M. KORCHAK, JOANN R. CUTILLI, CHARLES A. STANLEY, \\ LESTER BAKER, STEVEN D. DOUGLAS, AND LAURIE KILPATRICK \\ Deparment of Pediatrics, University of Pennsyliania School of Medicine, Children's Hospital of Philadelphia. \\ Philadelphia. Ponnsylvania 19104
}

\begin{abstract}
Glycogen storage disease (GSD) type $1 \mathrm{~b}$ is accompanied by decreased respiratory burst activity in peripheral blood phagocytic cells (i.e. monocytes and neutrophils). To elucidate whether this depressed respiratory burst was due to an intrinsic defect of phagocytic cells or due in part to in vivo host factors, we examined superoxide anion $\left(\mathrm{O}_{2}^{-}\right)$production in monocytes from five GSD 1b patients cultured $9 \mathrm{~d}$ in vitro to allow for differentiation into macrophages (MDM). $\mathrm{O}_{2}^{-}$production in MDM was measured in response to concanavalin $\mathrm{A}$, fMlet-Leu-Phe, and phorbol myristate acetate (PMA) stimulation. GSD Ib MDM had significantly depressed $\mathrm{O}_{2}^{-}$generation with nlet-Leu-Phe and concanavalin $A$ stimulation; however, unlike peripheral blood monocytes, GSD Ib MDM responded to PMA stimulation with $\mathrm{O}_{2}^{-}$production comparable to healthy control donors. The cytokine interferon- $\gamma$ (IFN- $\gamma$ ) has been shown to enhance $\mathrm{O}_{2}^{-}$production in MDM. When GSD $1 \mathrm{~b}$ MDM were cultured in the presence of IFN- $\gamma\left(1 \times 10^{5} \mathrm{U} / \mathrm{L}\right), \mathrm{O}_{2}^{-}$production in response to Met-Leu-Phe, concanavalin A, and PMA was enhanced to rates similar to those of control MDM cultured in the presence of IFN- $\gamma$. Thus, the respiratory burst defect observed in circulating phagocytic cells is also present in vitro in cultured GSD I b MDM. However, in contrast to circulating phagocytic cells, depressed $\mathrm{O}_{2}^{-}$production in GSD 1 b MDM is selective to receptor-mediated activation, but not to PMA stimulation. This defect is correctable after short-term treatment with IFN- $\gamma$, suggesting a role for IFN- $\gamma$ in treating the phagocytic defect in this disease. (Pediatr Res 34: 265-269, 1993)
\end{abstract}

\section{Abbreviations}

GSD, glycogen storage disease

$1 \mathrm{a}$ and $1 \mathrm{~b}$, types $1 \mathrm{a}$ and $1 \mathrm{~b}$ of GSD

$\mathrm{O}_{2}^{-}$, superoxide anion

MDM, monocyte-derived macrophage

IFN- $\gamma$, interferon- $\gamma$

PMIA, phorbol myristate acetate

Con A, concanavalin $\mathbf{A}$

$\mathrm{Ca}^{2+}$, calcium

Received October 8, 1992; accepted April 8, 1993.

Correspondence: Dr. Laurie Kilpatrick, Division of Allergy, Immunology and Infectious Diseases, Children's Hospital of Philadelphia, 34th St. and Civic Center Blvd., Philadelphia. PA 19104.

Supported by NIH Grants AI-24840 and RR-00240.
In both GSD $1 \mathrm{a}$ and $1 \mathrm{~b}$, hepatic defects prevent the conversion of glucose-6-phosphate to glucose resulting in hypoglycemia during fasting $(1,2)$. In GSD $1 \mathrm{a}$, the enzyme glucose-6-phosphatase is defective $(1,2)$, whereas in GSD $1 \mathrm{~b}$, the glucose-6-phosphate translocase is affected (3-5). The clinical features of GSD $1 \mathrm{~b}$ are similar to those of GSD la with the exception that patients with GSD $1 \mathrm{~b}$ are often neutropenic and suffer from recurrent bacterial infections suggesting an impairment in their immune system (611).

There is evidence of functional defects in the phagocytic cells from GSD $1 \mathrm{~b}$ patients that limit their ability to destroy invading microorganisms. Multiple functional abnormalities have been identified including chemotaxis, bactericidal activity, respiratory burst activity, and glucose transport (12-18). We previously demonstrated that the defect in respiratory burst activity was associated with impaired calcium mobilization and decreased intracellular calcium stores $(18,19)$. It is not apparent whether these phagocytic cell dysfunctions are a result of multiple defects or of a more fundamental membrane defect.

Previous studies on the respiratory burst of monocytes from GSD $1 \mathrm{~b}$ patients have focused exclusively on circulating cells (15, 18): however, in vivo, the circulating monocytes migrate into tissue, where they adhere and over time differentiate into mature macrophages (20). Both cell adherence and differentiation modulate the kinetics of the $\mathrm{O}_{2}^{-}$generation (21-24). It is not known whether GSD Ib macrophages also have defective respiratory burst activity.

Macrophages can be functionally modified in vitro through exposure to cytokines, such as IFN- $\gamma$. IFN- $\gamma$ is a potent macrophage activator that is secreted by $\mathrm{T}$ cells. Among its varied effects, in vitro incubation with IFN- $\gamma$ has been shown to stimulate cell differentiation and enhance respiratory burst activity in MDM (25-27). In addition, IFN- $\gamma$ has been used in vivo to improve respiratory burst activity in patients with chronic granulomatous disease, leprosy, and HIV infection (28-31).

The purposes of this study were 1 ) to determine whether the respiratory burst activity in macrophages was also defective in GSD $\mathrm{Ib}$ and 2) to establish the efficacy of IFN- $\gamma$ treatment on the depressed respiratory burst in GSD $1 \mathrm{~b}$. Similar to circulating phagocytic cells, MDM from GSD $1 \mathrm{~b}$ patients had a selective defect in $\mathrm{O}_{2}^{-}$generation in response to the ligands $\mathrm{fMet}-\mathrm{Leu}-\mathrm{Phe}$ and Con A. Accordingly, GSD Ib phagocytic cells have an intrinsic defect in respiratory burst activity that is not dependent on cellular environment. However, unlike the peripheral blood phagocytic cells, MDMi from GSD lb patients do not have a depressed respiratory burst in response to PMA. Therefore, the defect in GSD 1 b respiratory burst activity in response to PMA stimulation is corrected after in vitro culture and cell differentiation. In vitro culture of MDM from GSD $1 \mathrm{~b}$ patients with IFN- $\gamma$ enhanced $\mathrm{O}_{2}^{-}$production to levels similar to controls in 
response to either $\mathrm{AMet}-\mathrm{Leu}$-Phe or Con A. Moreover, a comparison of the cell cultures revealed that GSD 1b MDM showed morphologic differences in comparison to control cells that were ameliorated by IFN- $\gamma$ treatment. Thus, MDM from GSD $1 \mathrm{~b}$ patients have a selective defect in respiratory burst activity to ligand stimulation that can be corrected in vitro with IFN- $\gamma$.

\section{MATERIALS AND METHODS}

Study population. The study population consisted of five unrelated GSD 1b patients: two men aged 28 and 24 y and three girls aged 4,9 , and 13 y. Written permission was obtained from patients or their parents for all blood samples in accordance with policies of the Institutional Review Board at the Children's Hospital of Philadelphia. Control blood samples were obtained from healthy adults routinely used as donors in our laboratory.

Monocyte isolation and culture of MDM. Monocytes were isolated from heparinized venous blood $\left(1 \times 10^{4} \mathrm{U} / \mathrm{L}\right)$ and cultured as previously described (32). Mononuclear cells, separated from whole blood by Ficoll-Hypaque centrifugation, were suspended in Dulbecco's Modified Eagle Media (DMEM; GIBCO Laboratories, Grand Island, NY). The cell suspension was plated onto gelatin-coated tissue culture flasks and incubated at $37^{\circ} \mathrm{C}$ for $45 \mathrm{~min}$ in $5 \% \mathrm{CO}_{2}$. Nonadherent cells were removed by several washings. Adherent monocytes were detached by incubation with $5 \mathrm{mM}$ EDTA in DMEM with $10 \%$ horse serum (HS; GIBCO Laboratories), washed, and resuspended in DMEM supplemented with $10 \%$ FCS (Hyclone Laboratories, Logan, UT), $10 \% \mathrm{HS}$, L-glutamine $(4 \mathrm{mM})$, penicillin $\left(1 \times 10^{5} \mathrm{U} / \mathrm{L}\right)$, and streptomycin $(100 \mathrm{mg} / \mathrm{L})$. Cells were plated at $2.0-3.5 \times 10^{5}$ cells/polylysine-coated glass coverslip/well in 24-well tissue culture plates. After $24 \mathrm{~h}$ of incubation at $37^{\circ} \mathrm{C}$ in $5 \% \mathrm{CO}_{2}$, nonadherent cells were removed by aspiration and fresh medium was added in the presence or absence of $1 \times 10^{5} \mathrm{U} / \mathrm{L}$ of recombinant human IFN- $\gamma\left(1 \times 10^{5} \mathrm{U} / \mathrm{L}=100 \mathrm{U} / \mathrm{mL}\right)(\mathrm{Hoff}-$ man-La Roche, Nutley, NJ). Cell cultures were maintained at $37^{\circ} \mathrm{C}$ in $5 \% \mathrm{CO}_{2}$ for $9 \mathrm{~d}$.

$\mathrm{O}_{2}^{-}$generation. The generation of $\mathrm{O}_{2}^{-}$by $\mathrm{MDM}$ was measured on the 9 th $\mathrm{d}$ of culture in the well plate as superoxide dismutaseinhibitable cytochrome $c$ reduction by endpoint analysis (33).

DNA assay. DNA from MDM cultures was assayed according to a procedure adapted from West et al. (34). Ten mM EDTA, $\mathrm{pH} \mathrm{12.3,} \mathrm{were} \mathrm{added} \mathrm{to} \mathrm{each} \mathrm{well} \mathrm{and} \mathrm{incubated} \mathrm{for} 90 \mathrm{~min}$ at $37^{\circ} \mathrm{C}$. After the plates were cooled on ice, the $\mathrm{pH}$ was lowered to pH 7.0 with $1 \mathrm{M} \mathrm{KH}_{2} \mathrm{PO}_{4}$. The supernatants were incubated for 20 min with $9.0 \times 10^{-7} \mathrm{M}$ Hoescht no. 33258 (bisBenzimide; Sigma Chemical Co., St. Louis, MO) and diluted in $100 \mathrm{mM}$ $\mathrm{NaCl}-10 \mathrm{mM}$ Tris, $\mathrm{pH}$ 7.0. Fluorescence was measured using an excitation wavelength of $350 \mathrm{~nm}$ and an emission wavelength of $455 \mathrm{~nm}$. A standard curve from 0.31 to $10 \mu \mathrm{g}$ DNA was prepared from calf thymus DNA and sample concentrations were calculated allowing for a linear conversion of $\log$ (fluorescence) to $\log (\mu \mathrm{g}$ DNA).

Materials. PMA was purchased from Sigma, stored as a concentrated stock solution in DMSO, and diluted before use. IMetLeu-Phe (Sigma) was stored in stock solution of ethanol and diluted in buffer before use. Con A (Sigma) was prepared fresh before use.

\section{RESULTS}

Stimulation of MDM by a variety of stimuli elicits the assembly and activation of the NADPH oxidase, which catalyzes the reduction of oxygen to $\mathrm{O}_{2}^{-}$, the respiratory burst (35). We compared the respiratory burst activity of GSD $\mathrm{lb}$ and control MDM activated by $\mathrm{fMet}-\mathrm{Leu}-\mathrm{Phe}$ and by Con A, both surface receptor-mediated agonists, and also by the phorbol ester PMA, which acts at a site distal to plasma membrane receptors, thereby bypassing part of the receptor-activated signaling pathway. As shown in Figure $1 A$, stimulation of control MDM with either
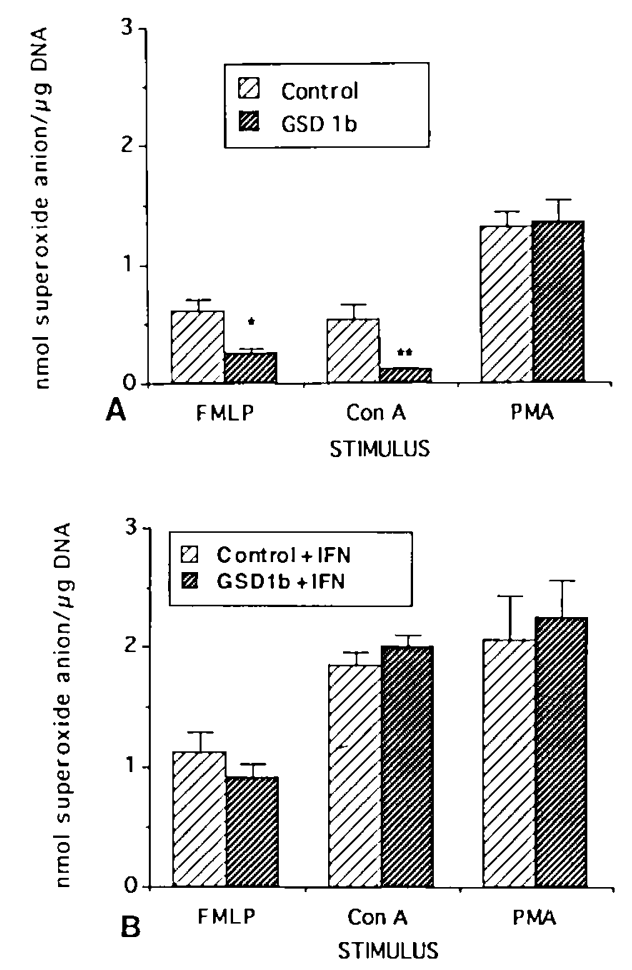

Fig. 1. $A, \mathrm{O}_{2}^{-}$generation in control and GSD $1 \mathrm{~b}$ MDM. MDM were cultured for $9 \mathrm{~d}$. $\mathrm{O}_{2}^{-}$was determined on $\mathrm{d} 9$ as superoxide dismutaseinhibitable cytochrome $c$ reduction by endpoint analysis after $60 \mathrm{~min}$ of stimulation in response to PMA $(0.1 \mathrm{mg} / \mathrm{L})$, fMct-Leu-Phe $\left(10^{-6} \mathrm{M}\right)$, or Con $A(100 \mathrm{mg} / \mathrm{L})$. Con A was added after a 5-min incubation of MDM with $5 \mathrm{mg} / \mathrm{L}$ cytochalasin $B$. Values are mean $\pm S E M$ of triplicate determinations for three to four individual patients with matched controls and are expressed as nmol $\mathrm{O}_{2}^{-} / \mu \mathrm{g}$ DNA. ${ }^{*}, p<0.02$ in Met-LeuPhe-stimulated control MDM is GSD $1 \mathrm{~b}$ MDM: ${ }^{* *}, p<0.03$ in Con A-stimulated control MDM is GSD lb MDM. $B, \mathrm{O}_{2}^{-}$generation in control and GSD Ib MDM cultured with IFN- $\gamma$. MDM were cultured for $9 \mathrm{~d}$ in the presence of IFN- $\gamma\left(1 \times 10^{5} \mathrm{U} / \mathrm{L}\right) . \mathrm{O}_{2}^{-}$was determined on $\mathrm{d} 9$ of culture in response to PMA, PMet-Leu-Phe, and Con A as described in $A$. Values are mean \pm SEM of triplicate determinations for three to four patients with matched controls and are expressed as nmol $\mathrm{O}_{2}^{-} / \mu \mathrm{g}$ DNA.

PMA, fMet-Leu-Phe, or Con A results in $\mathrm{O}_{2}{ }^{-}$production. Maximal $\mathrm{O}_{2}^{-}$production was obtained with PMA $(1.35 \pm 0.18 \mathrm{nmol}$ $\mathrm{O}_{2}^{-} / \mu \mathrm{g}$ DNA control MDM, mean $\pm \mathrm{SEM}, n=4$, which is equivalent to $12.7 \mathrm{nmol} \mathrm{O}_{2}^{-} / 10^{6}$ cells). This rate of PMAtriggered $\mathrm{O}_{2}^{-}$production in $\mathrm{MDM}$ is less than that of $\mathrm{O}_{2}^{-}$ production in freshly isolated monocytes and neutrophils as previously reported $(18,19,22-24)$.

IMet-Leu-Phe $\left(10^{-6} \mathrm{M}\right)$-stimulation of GSD $1 \mathrm{~b}$ MDM had significantly depressed $\mathrm{O}_{2}^{-}$generation as compared with controls $\left(0.25 \pm 0.05 \mathrm{nmol} \mathrm{O}_{2}^{-} / \mu \mathrm{g}\right.$ DNA GSD $1 \mathrm{~b}$ MDM versus $0.61 \pm$ $0.1 \mathrm{nmol} \mathrm{O}_{2}^{-} / \mu \mathrm{g}$ DNA control MDM, $\left.n=4, p<0.02\right)$. This reduction in $\mathrm{O}_{2}^{-}$production in GSD $1 \mathrm{~b} \mathrm{MDM}$ (42\% of controls) was similar to the reduction in respiratory burst activity we reported in GSD $1 \mathrm{~b}$ monocyte suspensions (32\% of controls, $n$ $=3$ patients) and neutrophils ( $17 \%$ of controls, $n=3$ patients) $(18,19)$. Defective generation of $\mathrm{O}_{2}^{-}$was also observed in GSD lb MDM stimulated with Con $\mathrm{A}\left(0.11 \pm 0.03 \mathrm{nmol} \mathrm{O}_{2}^{-} / \mu \mathrm{g}\right.$ DNA GSD 1b MDM versus $0.53 \pm 0.12 \mathrm{nmol} \mathrm{O}_{2}{ }^{-} / \mu \mathrm{g}$ DNA control MDM, $p<0.03, n=3$ ). In contrast, there was no difference between the rates of $\mathrm{O}_{2}^{-}$generation elicited by PMA in MDM from GSD $1 \mathrm{~b}$ patients and control donors $(1.35 \pm 0.18$ $\mathrm{nmol} \mathrm{O}{ }_{2}^{-} / \mu \mathrm{g}$ DNA and $1.30 \pm 0.14 \mathrm{nmol}{ }_{2}^{-} / \mu \mathrm{g}$ DNA, respectively, $n=4)$. Thus, MDM from GSD $1 \mathrm{~b}$ patients have a selective impairment of $\mathrm{O}_{2}^{-}$production in response to $\mathrm{fMet}-\mathrm{Leu}-\mathrm{Phe}$ and 
Con $\mathrm{A}$ but not to PMA stimulation compared with healthy controls.

Previous studies have demonstrated that the addition of IFN- $\gamma$ during cell culture enhances the respiratory burst activity of MDM upon subsequent stimulation $(26,27)$. Control MDM cultured in the presence of IFN- $\gamma$ had increased respiratory burst activity independent of the stimulus used (Fig. 1B). The $\mathrm{O}_{2}^{-}$ generation in control cells cultured with IFN- $\gamma$ was increased in response to PMA $(59 \%, p=\mathrm{NS})$, fMet-Leu-Phe $(79 \%, p<0.04)$, and Con A $(245 \%, p<0.01)$ stimulation compared with control MDM cultured in the absence of IFN- $\gamma$. IFN- $\gamma$ also increased $\mathrm{O}_{2}{ }^{-}$production in GSD $1 \mathrm{~b}$ MDM stimulated with $\mathrm{M}$ Met-Leu-Phe $(259 \%, p<0.01)$, Con A $(1700 \%, p<0.01)$, or PMA $(67 \%, p<$ $0.01)$ compared with GSD Ib MDM cultured with medium alone (Fig. $1 B$ ). There was no significant difference between the $\mathrm{O}_{2}{ }^{-}$generated by IFN- $\gamma$-treated GSD $1 \mathrm{~b}$ MDM by PMA, fMetLeu-Phe, and Con $\mathrm{A}$ and their respective controls. Thus, in vitro treatment of MDM with IFN- $\gamma$ corrected the defective response to fMet-Leu-Phe and Con A stimulation in MDM from GSD lb patients.

Figure 2 shows representative phase-contrast photomicrographs of MDM from control and GSD $1 \mathrm{~b}$ patients cultured in the presence or absence of $1 \times 10^{5} \mathrm{U} / \mathrm{L}$ IFN- $\gamma$. The control cultured MDM demonstrated the morphologic changes that accompany maturation of monocytes into MDM (Fig. 2B): evidence of cytoplasmic spreading and increased cell diameter (36). In contrast, the GSD $1 \mathrm{~b}$ MDM had smaller cell diameter and less cytoplasmic spreading (Fig. $2 A$ ). GSD $1 \mathrm{~b}$ MDM cultured in the presence of IFN- $\gamma$ responded with morphologic changes similar to those of control cells cultured with IFN- $\gamma$ addition (Fig. $2 C$ and $D$ ). Thus, the changes in respiratory burst activity of the GSD Ib MDM upon IFN- $\gamma$ treatment are paralleled by morphologic changes.
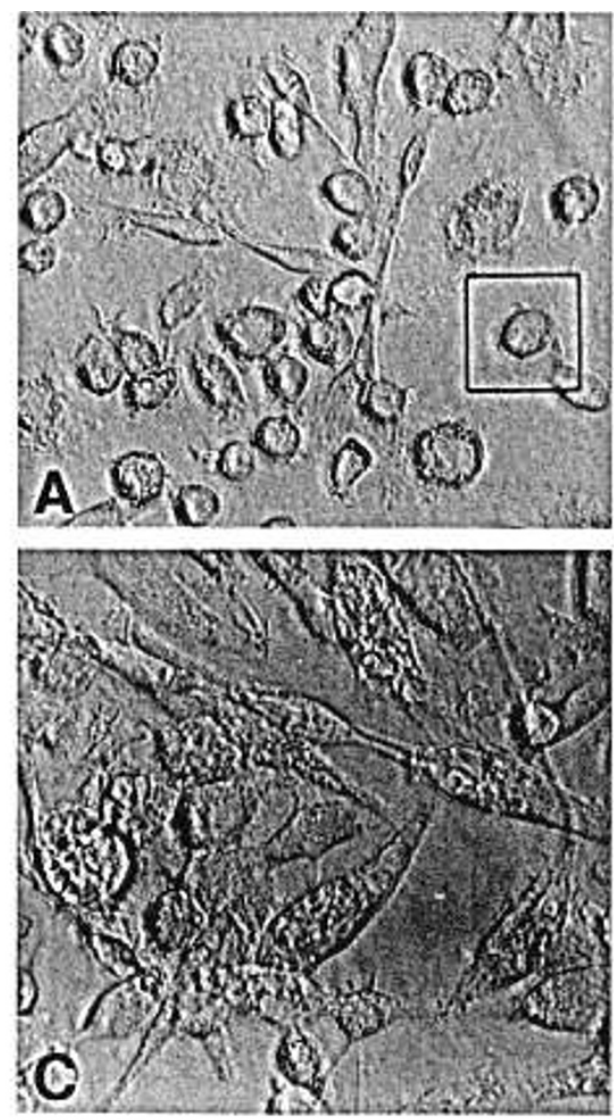

We and others have documented the defective respiratory burst activity in circulating phagocytic cells from GSD $1 \mathrm{~b}$ patients (10, $11,14,15,18,19)$. The results of the present study demonstrate that MDM cells from GSD $1 \mathrm{~b}$ patients are also defective in their ability to generate $\mathrm{O}_{2}{ }^{-}$in response to ligand (i.e. fMet-Leu-Phe and Con A) stimulation. The reproducibility of the observed depressed respiratory burst in GSD $1 \mathrm{~b}$ phagocytic cells cultured short-term in vitro indicates that the defect is intrinsic and is not a result solely of in vivo host factors.

This study also demonstrates that the PMA-stimulated respiratory burst activity in GSD $1 \mathrm{~b}$ MDM is equivalent to that of controls. Seger et al. (10) observed normal NADPH-dependent $\mathrm{O}_{2}^{-}$production in neutrophil lysates from a single GSD $1 \mathrm{~b}$ patient, which is consistent with our observation. These results suggest that the components that make up the NADPH oxidase are present in the cell and are fully functional. Thus, the GSD 1b patient's phagocytic cell defect differs from chronic granulomatous disease, which is distinguished by absent protein components of the NADPH oxidase enzyme complex and in which long-term in vivo therapy with IFN- $\gamma$ failed to improve the blunted respiratory burst (37-39).

The basis for the observation that PMA-stimulated $\mathrm{O}_{2}^{-}$production is defective in freshly isolated monocytes from GSD $1 \mathrm{~b}$ patients but not in vitro in MDM is not apparent but may be a result of alterations in the cellular environment. The presence of an inhibitory factor or the absence of a growth factor in the plasma of these patients may be responsible for the depressed PMA-triggered $\mathrm{O}_{2}^{-}$production. Alternatively, monocyte adherence and differentiation induces alterations in protein synthesis and cellular metabolism $(22,36)$. This results in decreased respiratory burst activity compared with peripheral blood mono-
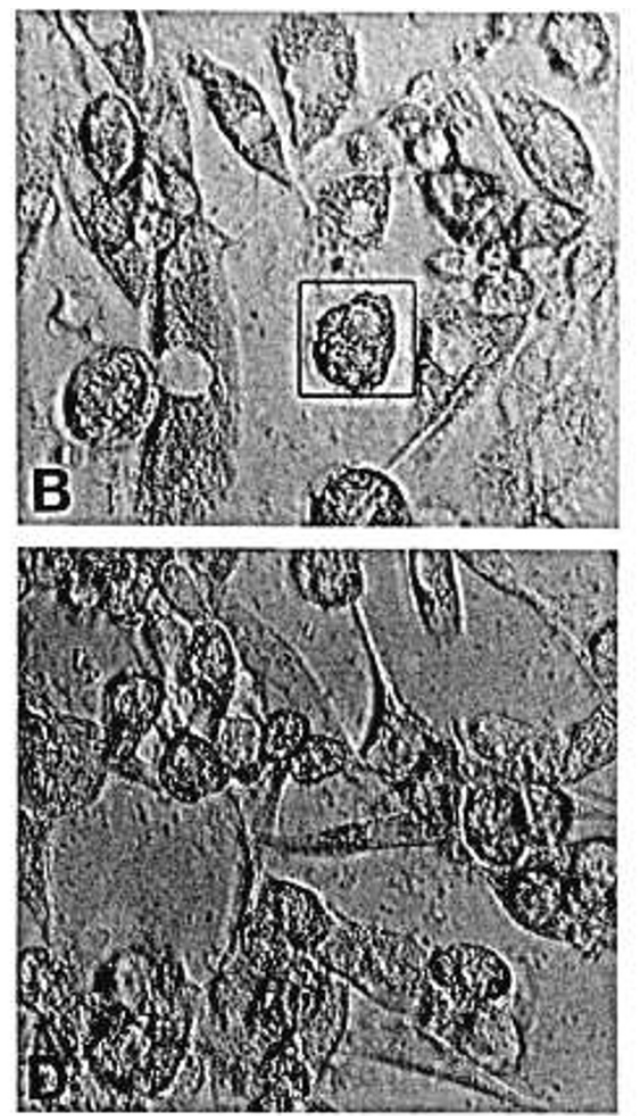

Fig. 2. Effect of IFN- $\gamma$ on morphology of control and GSD 1b MDM. Phase contrast photomicrographs were taken on d 9 of culture. A, GSD Ib MDM and $B$, control MDM cultured in medium alone $(\times 400)$. $C$. GSD $1 \mathrm{~b}$ MDM and $D$, control MDM cultured in the presence of IFN- $\gamma(1 \times$ $\left.10^{5} \mathrm{U} / \mathrm{L}\right)(\times 400)$. 
cytes and enhanced membrane depolarization and $\mathrm{Ca}^{2+}$ mobilization upon stimulation $(21-24)$. Thus, cellular alterations induced by cell adherence or differentiation may restore the PMAstimulated respiratory burst upon GSD $1 \mathrm{~b}$ monocyte maturation.

IFN- $\gamma$ addition during cell culture enhanced the respiratory burst activity in both control and GSD Ib MDM, thereby correcting the defective fMet-Leu-Phe- and Con A-elicited respiratory burst activity in GSD $1 \mathrm{~b}$ MDM. There are several different sites where IFN- $\gamma$ could alter respiratory activity in these patients' MDM; these include a direct effect on components of the NADPH oxidase enzyme complex, its assembly in the plasma membrane, or the signaling pathways that regulate the respiratory burst.

During monocyte maturation to macrophage, there is a downmodulation in the cells' ability to generate $\mathrm{O}_{2}^{-}(23,24)$. This has been attributed to down-modulation of the mRNA for constituents of the NADPH oxidase, specifically the membrane-associated gp91 and the cytosolic p47 components $(40,41)$. The culture of monocytes with IFN- $\gamma$ during maturation increases the expression of gp91 and $\mathrm{p} 47$, paralleling the increase in respiratory burst activity in these cells $(40,41)$. In addition, IFN- $\gamma$ alters the signaling pathways involved in regulating respiratory burst activity, specifically modulation of intracellular $\mathrm{Ca}^{2+}$ levels. Incubation with IFN- $\gamma$ increased the free intracellular $\mathrm{Ca}^{2+}$ levels in human monocytes (42) and in the monocytic cell line $\mathrm{U} 937$ (43). Furthermore, $\mathrm{Ca}^{2+}$ ionophores and phorbol esters, together, mimic the IFN- $\gamma$-enhanced cytocidal activity in macrophages (44). As stated previously, our results suggest that the respiratory burst defect is not due to decreased expression of the components of the NADPH oxidase itself. Thus, although up-regulation of gp91 and p47 after IFN- $\gamma$ treatment may be responsible for the overall increase in the potential rate of the respiratory burst, it is more likely that IFN- $\gamma$ corrects the respiratory burst defect in GSD Ib MDM by modulation of receptor expression and/or the signal transduction pathway through changes in intracellular $\mathrm{Ca}^{2+}$ levels.

The morphologic changes associated with IFN- $\gamma$ treatment of GSD 1b MDM suggests an IFN- $\gamma$-mediated effect on signal transduction. GSD $1 \mathrm{~b}$ MDM did not show cytoplasmic spreading or morphologic alterations concomitant with monocyte differentiation unless cultured in the presence of IFN- $\gamma$, which then resulted in morphologic changes similar to control cells. After adherence, a rise in intracellular $\mathrm{Ca}^{2+}$, similar to that in respiratory burst activity, is a necessary precedent to spreading in neutrophils (45). We have previously demonstrated depressed $\mathrm{Ca}^{2+}$ mobilization in GSD $1 \mathrm{~b}$ monocytes that is associated with decreased intracellular $\mathrm{Ca}^{2+}$ stores. This is suggestive of a common signaling defect affecting cytoplasmic spreading and respiratory burst activity in GSD lb patients, possibly at the level of or before $\mathrm{Ca}^{2+}$ mobilization.

The mechanism(s) by which IFN- $\gamma$ corrects the deficient ligand-elicited respiratory burst in GSD $1 \mathrm{~b}$ MDM remains to be elucidated. Defining the specific alteration(s) by which IFN- $\gamma$ normalizes the deficient respiratory burst activity in GSD $1 \mathrm{~b}$ MDM will provide further insight into the defect in GSD $1 \mathrm{~b}$ respiratory burst activity. In summary, the $\mathrm{O}_{2}^{-}$production in MDM from GSD $1 \mathrm{~b}$ patients was depressed in response to $\mathrm{PMet}$ Leu-Phe and Con A but not PMA stimulation. This selective defect in ligand-triggered $\mathrm{O}_{2}^{-}$generation can be corrected in vitro with IFN- $\gamma$, which suggests that IFN- $\gamma$ should be considered for the treatment of this defect in patients with GSD $1 \mathrm{~b}$.

\section{REFERENCES}

1. Cori GT, Cori CF 1952 Glucose-6-phosphate of liver in glycogen storage disease. J Biol Chem 199:661-667

2. Howell RR, Williams JC 1983 The glycogen storage diseases. In: Stanbury JB Wyngaarden JB, Fredrickson DS (eds) The Metabolic Basis of Inherited Disease, 5th Ed. McGraw-Hill, New York, pp 141-166

3. Senior B, Loridan L 1968 Studies of liver glycogenosis with particular reference to the metabolism of intravenously administered glycerol. N Engl J Med 279:958-965
4. Narisawa KY, Igarashi Y, Otomo H, Tada K 1978 A new variant of glycogen storage disease type 1 due to a defect in glucose-6-phosphate transport system. Biochem Biophys Res Commun 83:1360-1364

5. Lange AJ, Arion WJ, Beaudet AL 1980 Type $\mathrm{lb}$ glycogen storage disease is caused by a defect in the glucose-6-phosphate translocase of the microsomal glucose-6-phosphatase system. J Biol Chem 255:8381-8384

6. DiRocco MC. Borrone C. Dallegri F, Frumento G, Patrone F 1984 Neutropenia and impaired neutrophil function in glycogenosis type $\mathrm{lb}$. J Inherited Metab Dis $7: 151-154$

7. Schaub J, Heyne K 1983 Glycogen storage discase type lb. Eur J Pediatr 140:283-288

8. Beaudet AL, Anderson DC, Michels VV, Arion WJ, Lange AJ 1980 Neutropenia and impaired neutrophil migration in type $1 \mathrm{~b}$ glycogen storage disease. J Pediatr 97:906-910

9. Bartram CR, Przyrembel H, Wendel U, Bremer HJ, Schaub J, Hass JR 1981 Glycogenosis type lb complicated by severe granulocytopenia resembling inherited neutropenia. Eur J Pediatr 137:81-84

10. Seger R, Steinmann B, Tiefenauer L, Matsunaga T, Gitzelmann R 1984 Glycogenosis lb: neutrophil microbicidal defects due to impaired hexose monophosphate shunt. Pediatr Res 18:297-299

11. Narisawa K, Ishizawa S, Okumura H, Tada K. Kuzuya T 1986 Neutrophil metabolic dysfunction in genetically heterogeneous patients with glycogen storage disease type 1b. J Inherited Metab Dis 9:297-300

12. Koven NL, Clark MM, Cody CS, Stanley CA, Baker L, Douglas SD 1986 Impaired chemotaxis and neutrophil function in glycogenosis type $\mathrm{lb}$. Pediatr Res 20:438-442

13. Anderson DC, Mace ML, Brinkley BR, Martin RR, Smith CW 1981 Recurren infection in glycogenosis type 1b: abnormal neutrophil motility related to impaired redistribution of adhesion sites. J Infect Dis 143:447-459

14. Gahr M, Heyne K 1983 Impaired metabolic function of polymorphonuclear leukocytes in glycogen storage disease $1 \mathrm{~b}$. Eur J Pediatr 140:329-330

15. Ueno N, Tomita M, Ariga T, Ohkawa M, Nagano S, Takahashi Y, Arashima S, Matsumoto S 1986 Impaired monocyte function in glycogen storage disease type 1b. Eur J Pediatr 145:312-314

16. Bashan N, Hagai Y, Potashnik R, Moses SW 1988 Impaired carbohydrate metabolism of polymorphonuclear leukocytes in glycogen storage disease lb. J Clin Invest 81:1317-1322

17. Potashnik R, Moran A, Moses SW, Peleg N, Bashan N 1990 Hexose uptake and transport in polymorphonuclear leukocytes from patients with glycogen storage disease 1 b. Pediatr Res 28:19-23

18. Kilpatrick L, Garty B-Z, Lundquist KF, Hunter K, Stanley CA, Baker L. Douglas SD, Korchak HM 1990 Impaired metabolic function and signaling defects in phagocytic cells in glycogen storage disease type $\mathrm{lb}$. J Clin Invest $86: 196-202$

19. Korchak HM, Garty B-Z, Stanley CA, Baker L, Douglas SD, Kilpatrick L 1993 Impairment of calcium mobilization in phagocytic cells in glycogen storage disease type 1b. Eur J Pediatr 152(Suppl 1):S39-S43

20. Yoder MC, Hassan NF, Douglas SD 1992 Mononuclear phagocyte system. In Polin RA, Fox WW (eds) Fetal and Neonatal Physiology, Vol 2. WB Saunders Co, Philadelphia, pp 1438-1461

21. Dahinden CA, Fehr J, Hugli TE 1983 Role of cell surface contact in the kinetics of superoxide production by granulocytes. J Clin Invest 72:113-121

22. Bernardo J, Brink HF, Simons E 1988 Time dependence of transmembrane potential changes and intracellular calcium flux in stimulated human monocytes. J Cell Physiol 134:131-136

23. Nakagawara A, Nathan CF, Cohn ZA 1981 Hydrogen peroxide metabolism in human monocytes during differentiation in vitro. J Clin Invest 68:12431252

24. Musson RA, McPhail LC, Shafran H, Johnston Jr RB 1982 Differences in the ability of human peripheral blood monocytes and in vitro monocyte-derived macrophages to produce superoxide anion: studies with cells from normals and patients with chronic granulomatous disease. J Reticuloendothel Soc 32:261-266

25. Weinberg JB, Hobbs MM, Misukonis MA 1985 Phenotypic characterization of gamma interferon-induced human monocyte polykaryons. Blood 66:1241-1246

26. Nathan CF, Murray, HW, Wiebe ME, Rubin BY 1983 Identification of interferon-gamma as the lymphokine that activated human macrophage oxidative metabolism and antimicrobial activity. J Exp Med 158:670-689

27. Nathan CF, Prendergast TJ, Wiebe ME, Stanley ER, Platzer E, Remold HG, Welte K, Rubin BY, Murray HW 1984 Activation of human macrophages: comparison of other cytokines with interferon- $\gamma$. J Exp Med 160:600-605

28. Ezekowitz RAB, Dinauer MC, Jaffe HS, Orkin SH, Newburger PE 1988 Partial correction of the phagocyte defect in patients with X-linked chronic granulomatous disease by subcutaneous interferon gamma. $N$ Engl $\mathrm{J}$ Med 319:146-151

29. Sechler JM, Malech HL, White CJ, Gallin JI 1988 Recombinant human interferon- $\gamma$ reconstitutes defective phagocyte function in patients with chronic granulomatous disease. Proc Natl Acad Sci USA 85:4874-4878

30. Sampaio EP, Moreira AL, Sarno EN, Malta AM, Kaplan G 1992 Prolonged treatment with recombinant interferon gamma induces erythema nodosum leprosum in lepromatous leprosy patients. J Exp Med 175:1729-1737

31. Capsoni F, Minonzio F, Ongari AM, Rizzardi GP, Lazzarin A, Zanussi C 1992 Monocyte-derived macrophage function in HIV-infected subjects: in vitro modulation by rIFN- $\gamma$ and rGM-CSF. Clin Immunol Immunopathol $62: 176-182$ 
32. Hassan NF, Campbell DE, Douglas SD 1986 Purification of human monocytes on gelatin-coated surfaces. J Immunol Methods 95:273-276

33. Korchak HM, Weissmann G 1978 Changes in membrane potential of human granulocytes antecede the metabolic responses to surface stimulation. Proc Natl Acad Sci 75:3818-3822

34. West DC, Sattar A, Kumar S 1985 A simplified in situ procedure for the determination of DNA and cell number in tissue cultured mammalian cells. Anal Biochem 147:289-295

35. Clark RA 1990 The human neutrophil respiratory burst oxidase. J Infect Dis 161:1140-1147

36. Zuckerman SH, Ackerman SK, Douglas SD 1979 Long-term human peripheral blood monocyte cultures: establishment, metabolism and morphology of primary human monocyte-macrophage cell cultures. Immunology 38:401411

37. Segal AW 1989 The electron transport chain of the microbicidal oxidase of phagocytic cells and its involvement in the molecular pathology of chronic granulomatous disease. J Clin Invest 83:1785-1793

38. International Chronic Granulomatous Disease Cooperative Study Group 1991 A controlled trial of interferon gamma to prevent infection in chronic granulomatous disease. N Engl J Med 324:509-516

39. Woodman RC, Erickson RW, Rae J, Jaffe HS, Curnutte JT 1992 Prolonged recombinant interferon- $\gamma$ therapy in chronic granulomatous disease: evidence against enhanced neutrophil oxidase activity. Blood 79:1558-1562

40. Cassatella MA, Bazzoni F, Flynn RM. Dusi S, Trinchieri G, Rossi F 1990 Molecular basis of interferon- $\gamma$ and lipopolysaccharide enhancement of phagocyte respiratory burst capability: studies on the gene expression of several NADPH oxidase components. J Biol Chem 265:20241-20246

41. Cassatella MA, Bazzoni F, Amezaga MA, Rossi F 1991 Studies of the gene expression of several NADPH oxidase components. Biochem Soc Trans 19:63-67

42. Kemmerich B, Small GJ, Pennington JE 1986 Relation of cytosolic calcium to the microbicidal activation of blood monocytes by recombinant $\gamma$-interferon. J Infect Dis 154:770-777

43. Klein JB, Mcleish KR, Sonnenfeld G, Dean WL 1987 Potential mechanisms of cytosolic calcium modulation in interferon- $\gamma$ treated U937 cells. Biochem Biophys Res Commun 145:1295-1301

44. Celada A, Schreiber RD 1986 Role of protein kinase $C$ and intracellular calcium mobilization in the induction of macrophage tumoricidal activity by interferon- $\gamma$. J Immunol 137:2373-2379

45. Kruskal BA, Shak S, Maxfield FR 1986 Spreading of human neutrophils is immediately preceded by a large increase in cytoplasmic free calcium. Proc Natl Acad Sci USA 83:2919-2923 